\title{
Analisis Persediaan Bahan Baku pada UKM Kerupuk Subur Menggunakan Metode ABC dan Metode Lot Sizing
}

\author{
Ja'far Asshadhiq $^{1}$, Andrean Emaputra ${ }^{2 *}$, Kartinasari Ayuhikmatin Sekarjati $^{3}$ \\ 1,2,3 Teknik Industri, Fakultas Teknologi Industri, Institut Sains dan Teknologi AKPRIND Yogyakarta, \\ Yogyakarta, Indonesia \\ ( ${ }^{*}$ andrean.emaputra@akprind.ac.id)
}

\begin{abstract}
Abstrak - Persediaan merupakan suatu bahan atau barang yang disimpan dan akan digunakan pada waktu tertentu. Persediaan tersebut dibagi menjadi bahan baku, bahan separuh jadi, serta barang jadi. Persediaan bahan baku merupakan faktor terpenting dalam suatu proses produksi, karena jika terjadi kekurangan bahan baku selama proses produksi maka dapat menghambat kelangsungan proses produksi dan akan berakibat kerugian. Penelitian ini dilakukan pada UKM Kerupuk SUBUR, yang dimana memiliki gudang penyimpanan bahan baku yang minim dan diperlukan pengelompokan persediaan sesuai prioritas kebutuhan guna untuk meminimumkan kapasitas penyimpanan. Tujuan dari penelitian ini ialah untuk mengklasifikasi persediaan stok bahan baku dan meminimalkan total biaya persediaan. Penelitian ini menggunakan Metode ABC dan Metode Lot Sizing. Pada Metode Lot Sizing yang digunakan yakni Metode LFL, EOQ, dan POQ. Objek penelitian ini berfokus pada kerupuk ikan berbentuk mawar. Dari penelitian ini didapatkan hasil dari metode ABC yaitu katagori A tepung tapioka dan minyak, katagori B bawang putih dan ikan sarden, dan katagori C garam, ajinamoto, dan margarin. Pada metode Lot Sizing total cost paling rendah yaitu menggunakan metode LFL sebesar Rp.1.199.760.
\end{abstract}

Kata kunci: ABC; persediaan; Lot Sizing

\section{PENDAHULUAN}

Persediaan berperan penting dalam kelancaran suatu proses produksi, baik itu persedian bahan baku maupun bahan jadi. Apabila persediaan bahan baku tidak tercukupi, maka proses produksi dalam suatu perusahaan bisa terhambat sehingga untuk memenuhi kebutuhan konsumen perusahaan tersebut mengalami kesulitan dan berdampak kerugian. Perusahaan harus mempunyai persediaan yang cukup guna untuk menghindari ketidaksediaan pasar, karena selama proses produksi berlangsung tidak semua permintaan bahan baku terpenuhi secara langsung. Hal tersebut membutuhkan proses pemesanan dan bahan baku tersebut bisa datang terlambat. Persediaan bahan baku yang jumlahnya berlebihan mengakibatkan pertambahan biaya penyimpanan dan ketidakmerataan dalam pengalokasian modal yang mengakibatkan kekurangan modal untuk kebutuhan di luar produksi. Terlebih lagi, bahan baku yang melimpah dapat menyebabkan kerusakan pada bahan baku tersebut.

Pengadaan persediaan dapat menimbulkan biaya tambahan lain yaitu biaya permintaan, biaya pembelian, biaya pemeliharaan, biaya sewa gudang dan biaya kerugian. Oleh sebab itu, pengelolaan persediaan yang baik diharapkan dapat menghindari biaya persediaan tambahan dan meningkatkan pengelolaan keuangan secara tepat.

Industri kerupuk "Subur" merupakan salah satu dari sekian banyak produsen kerupuk yang berada di Yogyakarta. Penelitian ini bertujuan untuk mengklasifikasi persediaan stok bahan baku dan meminimalkan total biaya persedian. Pada pengamatan di UKM Kerupuk SUBUR masih belum melakukan pengadaan persedian bahan baku dengan baik. UKM Kerupuk SUBUR memproduksi kerupuk dalam jumlah besar yaitu sebanyak 40.000 kerupuk setiap harinya. Sehingga dibutuhkan ketersediaan stok guna memenuhi kebutuhan selama berlangsung proses produksi. Industri kerupuk SUBUR memesan bahan baku setiap satu minggu sekali dan masih menerapkan pengendalian persedian secara manual. Dimana industri kerupuk SUBUR melakukan pemesanan bahan baku ketika stok persedian bahan baku tersebut habis. Industri kerupuk SUBUR memiliki gudang penyimpanan bahan baku yang minim, sehingga diperlukan pengelompokan bahan baku sesuai prioritas kebutuhan guna untuk meminimumkan kapasitas penyimpanan. 


\section{STUDI LITERATUR}

Pada studi literatur, diambil beberapa contoh penelitian terdahulu sebagai bahan acuan dan perbandingan dalam melakukan penelitian yang akan dilakukan nanti. Metode yang bertujuan untuk meminimalisir biaya bahan baku yaitu metode ABC, LFL, EOQ, dan POQ. Metode tersebut telah dilakukan penelitian di berbagai jenis industri yang bertunjuan meminimalisir biaya, seperti industri kerupuk (Purnama \& Pulansari, 2020), industri manufaktur (Careza, Sudarso, \& Sadriatwati, 2017; Fithri \& Sindikia, 2016; Septiyana, 2017; Susmita \& Cahyana, 2018; Sutoni, 2018; Wicaksono, 2018), industri obat (Dyatmika \& Krisnadewara, 2017; Noviani, Nasution, \& Rizki, 2017; Resmana \& Rukmayadi, 2019), industri pengujian makanan dan minuman (Kinasih, R, K; Engelica, G, 2018).

Pada industri kerupuk SUBUR tersebut belum pernah dilakukan penelitian menggunakan metode ABC, Lot for Lot (LFL), Economic Order Quantity (EOQ), dan Period Order Quantity (POQ), sehingga penelitiaan dengan menggunakan metode tersebut, maka perusahaan memiliki nilai unsur kebauran (novelty).

\section{METODOLOGI}

\section{A. Analisis $A B C$}

Analisis $\mathrm{ABC}$ menggunakan prinsip diagram pareto yang dimana pemilihan barang berdasarkan tingkat penyerapan modal. Pada prinsip analisis $\mathrm{ABC}$ ini bertujuan untuk mengelompokkan jenis barang yang diserap dalam persediaan untuk setiap jenis barang berdasarkan tingkat investasi tahunan. Selain itu, diagram pareto dapat digambarkan dan membagi barang menjadi beberapa kategori. Maka dilakukan dengan Persamaan 1-4 sebagai berikut (Bahagia 2006):

$$
\begin{aligned}
& \mathrm{M}_{\mathrm{i}}=\mathrm{D}_{\mathrm{i} \times \mathrm{P}_{\mathrm{i}}} \\
& \mathrm{M}_{\mathrm{i}}=\sum_{\mathrm{i}} \mathrm{M}_{\mathrm{i}} \\
& \mathrm{P}_{\mathrm{i}}=\frac{M i}{M} \times 100 \% \\
& \mathrm{I}_{\mathrm{i}}=\frac{1}{N} \times 100 \%
\end{aligned}
$$

Persentase penyerapan dana diurutkan sesuai dengan besar persentase penyerapan dana dari terbesar sampai terkecil. Berdasarkan hasil urutan persentase penyerapan dana yang telah diperoleh, dihitung nilai kumulatif persentase penyerapan dana dan nilai kumulatif persentase kategori barang. Gambarlah diagram pareto pada diagram kartesius dengan sumbu ordinat menggunakan nilai persentase jenis barang dan sumbu absis menggunakan persentase penyerapan dana kemudian tentukan penggolongan barang berdasarkan prinsip Pareto.

\section{B. Peramalan}

Metode peramalan yang digunakan yaitu exponential smoothing, weighted moving average, linear trend, dan moving average kemudian dipilih Mean Absolute Deviation (MAD) yang terkecil. MAD dihitung dengan Persamaan 5 (Nasution dan Prasetyawan, 2008).

$$
\mathrm{MAD}=\left|\sum \frac{A t-F t}{n}\right|
$$

\section{Metode Lot For Lot (LFL)}

Metode Lot for Lot adalah sistem heuristic yang digunakan untuk menentukan jumlah lot yang dibutuhkan paling sederhana agar mudah dipahami. Pendapat dari metode ini merupakan penyedia (dari luar) tidak memerlukan jumlah lot pada permintaan khusus. Dimana, berapapun jumlah lot yang dipilih harus dapat dipenuhi. Untuk memperoleh metode Lot for Lot adalah seperti berikut (Bahagia, 2006):

1. Jumlah paket permintaan setara dengan jumlah permesanan pada periode perencanaan.

2. Pemesanan dilakukan periode L periode sebelum barang diperlukan. 


\section{Metode Economic Order Quantity (EOQ)}

Economic Order Quantity merupakan metode pengendalian persediaan untuk meminimalkan total biaya penyimpanan dan pemesanan. Metode EOQ ialah salah satu teknik pengendalian persediaan tertua dan paling terkenal (Render dan Heizer, 2010).

Rumus yang digunakan pada metode ini dengan persamaan berikut (Herjanto, 2003):

1. Menghitung jumlah pemesanan optimum unit per pesanan (EOQ) dengan Persamaan 6.

$$
\mathrm{Q}=\sqrt{\frac{2 D S}{H}}
$$

2. Menghitung frekuensi pemesanan per tahun dengan Persamaan 7.

$$
\mathrm{F}=\frac{D}{Q}
$$

E. Safety Stock

Safety stock dapat dihitung dengan Persamaan 8 (Herjanto, 1999).

$$
\text { ss }=\mathrm{Z} \times \sigma
$$

\section{F. Reorder Point}

Reorder Point merupakan batas ukuran stok persediaan yang harus tersedia pada waktu dilakukannya pemesanan kembali (Assauri, 2004). Maka reorder point dapat dihitung dengan Persamaan 9.

$$
\text { Reorder point }=(\mathrm{LT} \times \mathrm{AU})+\mathrm{SS}
$$

\section{G. Metode Period Order Quantity (POQ)}

Metode POQ adalah strategi untuk memastikan ukuran lot tergantung pada jumlah permintaan yang dicakup dalam periode tertentu, periode tersebut ditentukan berdasarkan pada rumus Wilson. Cara untuk menentukan rentang pemesanan tergantung pada persamaan Wilson dengan cara sebagai berikut (Bahagia, 2006).

1. Menghitung EOQ dengan rumus Persamaan 10.

$$
\mathrm{q}_{0}=\sqrt{\frac{2 A D}{h}}
$$

2. Hitung jumlah frekuensi pemesanan . Dapat dihitung dengan rumus Persamaan 11.

$$
\mathrm{F}=\left[\frac{D}{q 0}\right]
$$

3. Periode cakupan dapat dihitung dengan rumus Persamaan 12.

$$
\mathrm{T}=\frac{N}{f}
$$




\section{HASIL DAN PEMBAHASAN}

Pada penelitian ini, data yang didapatkan yaitu permintaan kerupuk pada industri kerupuk subur pada Juli sampai Desember 2020 dapat dilihat pada Tabel 1.

Tabel 1

Data Permintaan

\begin{tabular}{|l|c|}
\hline \multicolumn{1}{|c|}{ Bulan } & Penjualan (Buah) \\
\hline Juli & 883890 \\
\hline Agustus & 860180 \\
\hline September & 836260 \\
\hline Oktober & 879370 \\
\hline November & 855680 \\
\hline Desember & 858430 \\
\hline
\end{tabular}

\section{A. Analisis $A B C$}

Berdasarkan hasil perhitungan dapat dilihat bahwa jumlah penyerapan dana untuk tepung tapioka pada periode Juli - Desember 2020 Dapat dilihat pada Tabel 2.

Tabel 2

Persentase Kumulatif Penyerapan Dana

\begin{tabular}{|l|l|l|l|l|l|}
\hline Bahan Baku & $\begin{array}{l}\text { Persentase } \\
\text { Penyerapan } \\
\text { Dana (\%) }\end{array}$ & $\begin{array}{l}\text { Persentase } \\
\text { kumulatif item } \\
\text { jenis barang (\%) }\end{array}$ & $\begin{array}{l}\text { Persentase item } \\
\text { jenis barang (\%) }\end{array}$ & $\begin{array}{l}\text { Persentase } \\
\text { kumulatif item } \\
\text { jenis barang (\%) }\end{array}$ & Katagori \\
\hline Tepung tapioka & 57,12 & 57,12 & 14,3 & 14,3 & $\mathrm{~A}$ \\
\hline Minyak Goreng & 28,67 & 85,79 & 14,3 & 28,6 & $\mathrm{~A}$ \\
\hline Bawang putih & 4,75 & 90,54 & 14,3 & 42,9 & $\mathrm{~B}$ \\
\hline Ikan Sarden & 4,71 & 95,25 & 14,3 & 57,2 & $\mathrm{~B}$ \\
\hline Garam & 2,88 & 98,13 & 14,3 & 71,5 & $\mathrm{C}$ \\
\hline Ajinamoto & 1,29 & 99,42 & 14,3 & 100 & $\mathrm{C}$ \\
\hline Mentega & 0,58 & 100 & 14,3 & $\mathrm{C}$ \\
\hline
\end{tabular}

Pada hasil perhitungan di atas, maka persediaan bahan baku dapat dikatagorikan dengan menggunakan analisis $\mathrm{ABC}$ yaitu katagori $\mathrm{A}$ memiliki dua jenis persedian bahan baku yaitu tepung tapioca dan minyak goreng. Katagori B memiliki dua jenis persedian bahan baku yaitu bawang putih dan ikan sarden. Katagori $\mathrm{C}$ memiliki tiga jenis persedian bahan baku yaitu garam, ajinamoto dan margarin.

\section{B. Permintaan Kebutuhan}

Pada penelitian ini digunakan beberapa metode peramalan yaitu exponential smoothing, weighted moving average, linear trend, dan moving average. Software Pom-qm digunakan untuk menghitung metode peramalan yang bertujuan untuk menentukan MAD yang paling kecil. Data nilai MAD terkecil dapat dilihat pada Tabel 3.

Tabel 3

Kesalahan Peramalan Permintaan

\begin{tabular}{|l|l|l|}
\hline No. & Metode Peramalan & MAD \\
\hline 1. & weighted moving average & 20356.64 \\
\hline 2. & moving average & 19538.75 \\
\hline 3. & linear trend & 12060.21 \\
\hline 4. & exponential smoothing & 19715.13 \\
\hline
\end{tabular}

Dari data di atas, kesalahan peramalan permintaan paling kecil adalah metode linear trend sehingga metode ini digunakan untuk meramalkan data penjualan Industri kerupuk subur pada periode ke depannya, yaitu bulan Juli-Desember 2021 yang dapat dilihat pada Tabel 4 . 
Tabel 4

Peramalan Permintaan

\begin{tabular}{|l|c|}
\hline \multicolumn{1}{|c|}{ Bulan } & Permintaan (Buah) \\
\hline Juli & 852533 \\
\hline Agustus & 849541 \\
\hline September & 846950 \\
\hline Oktober & 844160 \\
\hline November & 841368 \\
\hline Desember & 838577 \\
\hline
\end{tabular}

Dari hasil peramalan yang didapat maka perhitungan kebutuhan bahan baku pada permintaan JuliDesember 2021yang dapat dilihat pada Tabel 5:

Tabel 5

Daftar Perencanaan Kebutuhan Bahan Baku

\begin{tabular}{|l|c|c|c|c|c|c|c|}
\hline \multicolumn{1}{|c|}{ Bulan } & $\begin{array}{c}\text { Tepung } \\
\text { Tapioka (kg) }\end{array}$ & $\begin{array}{c}\text { Garam } \\
(\mathbf{k g})\end{array}$ & $\begin{array}{c}\text { Bawang } \\
\text { Putih (kg) }\end{array}$ & $\begin{array}{c}\text { Ikan } \\
\text { Laut (kg) }\end{array}$ & $\begin{array}{c}\text { Minyak } \\
(\mathbf{k g})\end{array}$ & $\begin{array}{c}\text { Ajinamoto } \\
\text { (kg) }\end{array}$ & $\begin{array}{c}\text { Mentega } \\
\text { (kg) }\end{array}$ \\
\hline Juli & 6096 & 320 & 213 & 213 & 2749 & 43 & 43 \\
\hline Agustus & 6075 & 319 & 212 & 212 & 2740 & 43 & 43 \\
\hline September & 6055 & 318 & 212 & 212 & 2731 & 42 & 42 \\
\hline October & 6035 & 317 & 211 & 211 & 2722 & 42 & 42 \\
\hline November & 6015 & 315 & 210 & 210 & 2713 & 42 & 42 \\
\hline Desember & 5995 & 314 & 210 & 210 & 2703 & 42 & 42 \\
\hline Total & 36271 & 1903 & 1268 & 1268 & 16358 & 254 & 254 \\
\hline
\end{tabular}

C. Safety Stock dan Reorder Point

Dari perhitungan di atas dapat dilihat safety stock dan Reorder Point persediaan bahan baku pada Tabel 6 .

Tabel 6

Safety Stock Persediaan Bahan Baku

\begin{tabular}{|l|c|c|}
\hline \multicolumn{1}{|c|}{ Bahan Baku } & $\begin{array}{c}\text { Safety Stock } \\
\text { (kg) }\end{array}$ & $\begin{array}{c}\text { Reorder Point } \\
\text { (kg) }\end{array}$ \\
\hline Tepung Tapioka & 63 & 265 \\
\hline Garam & 4 & 15 \\
\hline Bawang Putih & 4 & 12 \\
\hline Ikan Sarden & 4 & 12 \\
\hline Minyak & 29 & 120 \\
\hline Ajinamoto & 1 & 3 \\
\hline Mentega & 1 & 3 \\
\hline
\end{tabular}

\section{Perhitungan Metode Lot Sizing}

1. Metode Lot For Lot

Perhitungan menggunakan metode LFL pada tepung tapioka dapat dilihat pada Tabel 7.

Tabel 7

Perhitungan LFL Pada Tepung Tapioka

\begin{tabular}{|l|c|c|c|c|c|c|c|c|}
\hline & \multicolumn{7}{|c|}{ Periode (bulan) } & \\
\hline \multicolumn{1}{|c|}{ Tepung Tapioka } & $\mathbf{0}$ & $\mathbf{1}$ & $\mathbf{2}$ & $\mathbf{3}$ & $\mathbf{4}$ & $\mathbf{5}$ & $\mathbf{6}$ & \\
\hline GR & 0 & 6096 & 6075 & 6055 & 6035 & 6015 & 5995 & \\
\hline OH & 0 & 0 & 0 & 0 & 0 & 0 & 0 & \\
\hline POR & 6096 & 6075 & 6055 & 6035 & 6015 & 5995 & & \\
\hline Holding Cost Rp.208/unit & 0 & 0 & 0 & 0 & 0 & 0 & 0 & 0 \\
\hline Setup Cost Rp.126.000/POR & 126.000 & 126.000 & 126.000 & 126.000 & 126.000 & 126.000 & & 765.000 \\
\hline \multicolumn{8}{|c|}{ TOTAL } \\
\hline
\end{tabular}




\section{Metode Economic Order Quantity}

Perencanaan kebutuhan baku dapat dilihat dari Tabel 8.

Tabel 8

Daftar Bahan Baku

\begin{tabular}{|l|c|c|c|c|}
\hline \multicolumn{1}{|c|}{ Bahan Baku } & Kebutuhan & $\begin{array}{c}\text { Biaya Pesan } \\
(\mathbf{R p})\end{array}$ & $\begin{array}{c}\text { Biaya Simpan } \\
(\mathbf{R p})\end{array}$ & $\begin{array}{c}\text { Harga } \\
(\mathbf{R p})\end{array}$ \\
\hline Tepung Tapioka & 36271 & 126.060 & 208 & 10.400 \\
\hline Garam & 1903 & 6.620 & 100 & 5.000 \\
\hline Bawang Putih & 1268 & 4.400 & 494 & 24.700 \\
\hline Ikan Sarden & 1268 & 4.400 & 490 & 24.500 \\
\hline Minyak & 16358 & 56.840 & 232 & 11.600 \\
\hline Ajinamoto & 254 & 840 & 680 & 34.000 \\
\hline Mentega & 254 & 840 & 300 & 15.000 \\
\hline
\end{tabular}

Sebagai contoh:

Tepung Tapioka

- Jumlah pemesanan ekonomis:

$$
\begin{aligned}
\text { EOQ }=\mathrm{Q} & =\sqrt{\frac{2 . D . S}{H}} \\
& =\sqrt{\frac{2 \times 36271 \times 126060}{208}} \\
& =6631 \mathrm{Kg}
\end{aligned}
$$

- Frekuensi pemesanan

$$
\begin{aligned}
\mathrm{F} \quad & =\frac{D}{Q} \\
& =\frac{36271}{6631} \\
& =5,47 \approx 6 \mathrm{kali}
\end{aligned}
$$

\begin{tabular}{|c|c|c|c|c|c|c|c|c|}
\hline & \multicolumn{7}{|c|}{ Periode (bulan) } & \\
\hline Tepung Tapioka & $\mathbf{0}$ & 1 & 2 & 3 & 4 & 5 & 6 & \\
\hline GR & 0 & 6096 & 6075 & 6055 & 6035 & 6015 & 5995 & \\
\hline $\mathrm{OH}$ & 0 & 535 & 1091 & 1667 & 2263 & 2879 & 3515 & \\
\hline POR & 6631 & 6631 & 6631 & 6631 & 6631 & 6631 & & \\
\hline Holding Cost Rp.208 /unit & 0 & 111.280 & 226.928 & 346.736 & 470.704 & 598.832 & 731.120 & 2.485600 \\
\hline Setup Cost Rp.126.000/POR & 126.000 & 126.000 & 126.000 & 126.000 & 126.000 & 126.000 & & 765.000 \\
\hline TOTAL & & & & & & & & 3.250 .600 \\
\hline
\end{tabular}

Perhitungan dengan memakai metode EOQ pada tepung tapioka dapat dilihat pada Tabel 9.

Tabel 9

Perhitungan EOQ Pada Tepung Tapioka

\section{Metode Period Order Quantity}

Penentuan metode POQ dilakukan sebagai berikut:

- Menghitung EOQ

$$
\mathrm{EOQ}=6631
$$

- Hitung frekuensi pemesanan

$$
\begin{array}{ll}
\mathrm{F} & =\left[\frac{D}{q 0}\right] \\
\mathrm{F} & =\left[\frac{36271}{6631}\right] \\
\mathrm{F} & =5.47=6
\end{array}
$$


- Periode cakupan

$$
\begin{aligned}
\mathrm{T} & =\frac{N}{f} \\
\mathrm{~T} & =\frac{24}{6} \\
\mathrm{~T} & =4 \text { periode }
\end{aligned}
$$

Perhitungan dengan menggunakan metode POQ pada tepung tapioka dapat dilihat pada Tabel 10.

\begin{tabular}{|c|c|c|c|c|c|c|c|c|}
\hline & \multicolumn{7}{|c|}{ Periode (bulan) } & \\
\hline Tepung Tapioka & $\mathbf{0}$ & 1 & 2 & 3 & 4 & 5 & 6 & \\
\hline$\overline{G R}$ & 0 & 6096 & 6075 & 6055 & 6035 & 6015 & 5995 & \\
\hline $\mathrm{OH}$ & 0 & 18165 & 12090 & 6035 & 0 & 5995 & 0 & \\
\hline POR & 24261 & & & & 12010 & & & \\
\hline Holding Cost Rp.208/unit & 0 & 3.778 .320 & 2.514 .720 & 1.255 .280 & & 1.246 .960 & & 8.795 .280 \\
\hline Setup Cost Rp.126.000/POR & 126.000 & & & & 126.000 & & & 252.000 \\
\hline TOTAL & & & & & & & & 9.047 .280 \\
\hline
\end{tabular}

Tabel 10

Perhitungan POQ Pada Tepung Tapioka

Dari hasil perhitungan menggunakan metode Lot For Lot (LFL), Economic Order Quantity (EOQ), dan Period Order Quantity (POQ) didapat total biaya cost pada metode LFL pada periode Juli-Desember 2021 sebesar Rp.1.199.760. Total biaya cost dengan menggunakan metode EOQ pada periode Juli-Desember 2021 sebesar Rp.4.912.040. Total biaya cost dengan menggunakan metode POQ pada periode Juli-Desember 2021 sebesar Rp.15.592.896. Sehingga total cost termurah yaitu metode LFL sebesar Rp. 1.199.760. Dapat dilihat berdasarkan Tabel 11.

Tabel 11

Total Biaya Cost Dengan Metode Lot Sizing

\begin{tabular}{|l|l|l|l|l|l|}
\hline No. & Bahan Baku & LFL & EOQ & POQ & TC Minimum(metode) \\
\hline 1. & Tepung Terigu & Rp.756.000 & Rp.3.250.600 & Rp.9.047.280 & LFL \\
\hline 2. & Garam & Rp.39.720 & Rp.161.480 & Rp.480.220 & LFL \\
\hline 3. & Bawang Putih & Rp.26.400 & Rp.284.624 & Rp.634.204 & LFL \\
\hline 4. & Ikan Sarden & Rp.26.400 & Rp.290.970 & Rp.629.140 & LFL \\
\hline 5. & Minyak & Rp.340.920 & Rp.813.856 & Rp.4.538.152 & LFL \\
\hline 6. & Ajinamoto & Rp.5.040 & Rp.64.730 & Rp.173.720 & LFL \\
\hline 7. & Mentega & Rp.5.040 & Rp.45.780 & Rp.90.180 & LFL \\
\hline \multicolumn{2}{|l|}{ Total } & Rp.1.199.520 & Rp.4.912.040 & Rp.15.592.896 & LFL \\
\hline
\end{tabular}

\section{KESIMPULAN}

Dari hasil pengolahan data, maka dapat diklasifikasikan persediaan bahan baku dengan mengunakan Analisis $\mathrm{ABC}$ yaitu katagori A memiliki dua jenis persedian bahan baku yaitu tepung tapioka dengan persentase penyerapan dana sebesar $57,12 \%$ dan pada minyak goreng persentase penyerapan dana sebesar $28,67 \%$. Katagori B memiliki dua jenis persedian bahan baku yaitu bawang putih dengan persentase penyerapan dana sebesar $4,75 \%$ dan ikan sarden dengan persentase penyerapan dana sebesar $4,71 \%$. Katagori $\mathrm{C}$ memiliki tiga jenis persedian bahan baku yaitu garam dengan persentase penyerapan dana sebesar 2,88\%, ajinamoto dengan persentase penyerapan dana sebesar 1,29\% dan margarin dengan persentase penyerapan dana sebesar $0,58 \%$. Berdasarkan perhitungan ongkos total dari perhitungan LFL, EOQ, POQ terdapat biaya total ongkos pada metode LFL pada periode Juli-Desember 2021 sebesar Rp.1.199.760. Total biaya total ongkos dengan memakai metode EOQ pada periode Juli-Desember 2021 sebesar Rp.4.912.040. Total biaya total ongkos dengan memakai metode POQ pada periode Juli-Desember 2021 sebesar Rp.15.592.896. Sehingga didapat ongkos termurah pada metode LFL sebesar Rp. 1.199.760. 


\section{DAFTAR PUSTAKA}

Assauri, S. 2004. Manajemen Produksi dan Operasi. Edisi. Jakarta. Lembaga Fakultas Ekonomi Universitas Indonesia

Bahagia, S.N. 2006, "Sistem Inventori”, Bandung: Penerbit ITB

Careza, R., Sudarso, Y., \& Sadriatwati, S. E. (2017). Analisis Perbandingan Metode EOQ dan Metode POQ dengan Metode Min-Max dalam Pengendalian Persediaan Bahan Baku pada PT Sidomuncul Pupuk Nusantara. Admisi Dan Bisnis, 17(1), 11-22.

Dyatmika, S. B., \& Krisnadewara, P. D. (2017). Pengendalian Persediaan Obat Generik Dengan Metode Analisis Abc, Metode Economic Order Quantity (Eoq), Dan Reorder Point (Rop) Di Apotek Xyz Tahun 2017. Journal of Chemical Information and Modeling, 30(1), 1689-1699.

Fithri, P., \& Sindikia, A. (2016). Pengendalian Persediaan Pozzolan di PT Semen Padang. Jurnal Optimasi Sistem Industri, 13(2), 665. https://doi.org/10.25077/josi.v13.n2.p665-686.2014

Heizer, J., dan Barry, R. 2010. "Operations Management: Manajemen Operasi”, Buku 2. Edisi Kesembilan, Jakarta: Salemba Empat.

Herjanto, E. 1999. Manajemen Produksi Dan Operasi. Edisi Kedua. PT. Gramedia Widiasarana Indonesia. Jakarta.

Herjanto, E. 2003. Manajemen Produksi \& Operasi Edisi Kedua. Jakarta: Gramedia Widiasarana Indonesia (Grasindo).

Kinasih, R, K; Engelica, G, R. (2018). Analisa Persediaan Bahan Baku Fast Flowing PT XYZ Menggunakan Metode Analisis ABC, Peramalan, Dan EOQ. 1(1), 61-75.

Nasution, A.H dan Prasetyawan. Y. 2008. Perencanaan \& Pengendalian Produksi. Yogyakarta: Graha Ilmu

Noviani, R., Nasution, Y. N., \& Rizki, A. (2017). Klasifikasi Persediaan Barang Menggunakan Analisis Always Better Control (ABC) dan Prediksi Permintaan dengan Metode Monte Carlo (Studi Kasus: Persediaan Obat Pada Apotek Mega Rizki Tahun 2016) ABC Analysis in Inventory Classification and Prediction. Journal EKSPONENSIAL, 8(2), 103-110.

Purnama, D. H. D., \& Pulansari, F. (2020). Perencanaan Dan Pengendalian Bahan Baku Produksi Kerupuk Dengan Metode Mrp Untuk Meminimumkan Biaya Persediaan Bahan Baku Di Ud. Xyz. Juminten: Jurnal Manajemen Industri Dan Teknologi, 01(04), 49-57. D. Juminten: Jurnal Manajemen Industri Dan Teknologi, 01(04), 49-57.

Resmana, D., \& Rukmayadi, D. (2019). Analisis Pengendalian Persediaan Obat generik Dengan Metode ABC Dan Metode Economic Order Quantity (EOQ) Di Apotek Anugerah Farma Bintaro. Teknik Industri, 228235.

Septiyana, D. (2017). Penggunaan Metode Poq (Periode Order Quantity) Dalam Upaya Pengendalian Tingkat Persediaan Bahan Baku (Hdn) (Studi Kasus Pada Perusahaan Fragrance Di Tangerang). Jurnal Teknik, 5(1). https://doi.org/10.31000/jt.v5i1.330

Susmita, A., \& Cahyana, B. J. (2018). Pemeliharaan Metode Permintaan Dan Perencanaan Kebutuhan Bahan Baku Dengan Metode MRP Di PT. XYZ.

Sutoni, A. (2018). Analisis Persediaan Menggunakan Metode Periodic Order Quantity (Poq) (Studi Kasus: Di Bb Barokah Cianjur). Journals.Upi-Yai. Ac. Id, 2(3), 55-61. Retrieved from http://journals.upiyai.ac.id/index.php/ikraith-teknologi/article/view/332

Wicaksono, A. (2018). Metode Period Order Quantity (POQ) Pada Sistem Inventori Perusahaan Manufaktur Modifikasi Motor. Teknik Industri, 3. 